\title{
Application of Remote Sensing and Geoinformatics Techniques in Erosion Mapping and Groundwater Management in the River Amba Watershed, Central Nigeria
}

\author{
Nuhu Degree Umar ${ }^{\mathrm{a}, *}$, Aliyu Itari Abdullahi ${ }^{\mathrm{b}}$ \\ ${ }^{a}$ Department of Geology, Federal University of Lafia, Nasarawa state, Nigeria \\ ${ }^{b}$ Department of Geology, University of Nigeria, Nsukka, Enugu state, Nigeria
}

\begin{abstract}
This research integrated an easy-to-handle remote sensing data and geoinformatics techniques for erosion mapping and groundwater management in the River Amba watershed, central Nigeria. It is aimed at: (a) the determination of the erosion prone areas, and (b) the estimation of the groundwater potential contamination risk under current and future anthropogenic activities. Rainfall intensity was evaluated from monthly rainfall data (2001 - 2011) from station located within the River Amba Watershed. Digital Elevation Model (DEM) for the terrain was created using 3D Analyst tool (Surfer 14) and was used to determine the flow direction and lineament features in each raster cells. Remote sensing data (aerial photographs and LANDSAT imagery) were used to develop land use map, while geological mapping was used to determine the local geology of the watershed area. The contributions of the various factors to the erosion hazardous areas are: elevation $31.49 \%$, land use $21 \%$, slope $14 \%$, geology $12.52 \%$, rainfall intensity $10.5 \%$ and flow accumulation $10.5 \%$. The combined influences of these factors to erosion susceptibility as either: very high, high, moderate, low and very low withthe south-western part characterized as high while other parts of the study area moderate to very low erosion vulnerability. The groundwater level is shallow $(4.0-28.5 \mathrm{~m})$ and discharges through the Amba river and many springs. These springs along with boreholes and wells supply drinking water to Lafia and environs.
\end{abstract}

DOI:10.46481/jnsps.2021.63

Keywords: Erosion, River Amba, Watershed, Landsat imagery, GIS

Article History :

Received: 17 March 2020

Received in revised form: 18 March 2021

Accepted for publication: 03 April 2021

Published: 29 May 2021

(C)2021 Journal of the Nigerian Society of Physical Sciences. All rights reserved. Communicated by: O. J. Abimbola

\section{Introduction}

Erosion is the removal and transport of soil, rock debris, or weathered materials by the action of water, wind, air and human activities from one location to another on the Earth's crust. This process is selective in a way as it removes mainly fine particles that contain relatively high proportion of organic matter. This

${ }^{*}$ Corresponding author tel. no: +2347069247822

Email address: aliyu.itari@gmail.com (Aliyu Itari Abdullahi) portion of the soil that is always removed is very rich in fertility and therefore supports plants growth. Soil erosion therefore, remains the main mechanism of soil degradation which threatens the global sustainability of the food production systems [1].

In the Amba watershed, soil erosion has often been exacerbated by crude agricultural practices, and particularly nonimplementation of appropriate soil conservation measures such as crop rotation, run-off control and contour farming. Studies showed that soil degradation leads to the loss of basic soil properties relevant to the farming system and/or an increase of the 
production costs [2].

Significant increase in erosion has been recorded all around the world in the last three decades especially in the tropics. These events which are quickly transformed into runoff, due to the high capacity of transport, can be characterized as the most significant weather-related hazards in many parts of the tropics all around the world, causing considerable economic and human losses [3]. The main causes of erosion are climate change, changes in land use and other anthropogenic interventions. The most common anthropogenic interventions are urban growth, the partial or total cover of torrent banks, watercourse alignment, improperly dimensioned bridges, deforestation and the consequent erosion, the construction of roads or other structures across the watercourse, subsidence observed in flat regions due to anthropogenic interventions such as over-pumping, and finally, the change or deviation of the watercourse [4].

Due to rapid urbanization and economic growth in Lafia in the past two decades, large percentage of cultivated land and forest land have been built up. Areas where deforestation, farming or urbanization leads to the formation of direct runoff will be more prone to erosion than areas where land use changes such as afforestation minimizes direct runoff [5]. One of the major contributing factors of erosion is rainfall: the degree of impact is dependent on its intensity, distribution, duration, frequency and kinetic energy. Erosion induced by rainfall causes many problems such as decreased in agricultural productivity due to the loss of arable land, increased landslide activity and ecosystem disturbance [6].

The lack of detailed climatic and hydrogeological data which are expensive and time consuming is a hindrance to the use of detail modelling approach. Thus, in erosion studies, precipitation records and flow data have been widely used [7]. Thus, the effective use of Geographic Information Systems (GIS) management tool is essential to delineate the flood prone areas [8]. Furthermore, the synthesis of available data and the mapping of the relationships between groundwater hazard and the elements at risk require the use of tools such as GIS. Integrating GIS and remote sensing techniques can provide the base for analyzing quantitatively environmental process with an appropriate degree of accuracy.

Whereas research has been conducted into the geology [9, 10], mineral resources [11], hydrogeology $[9,12]$ and aquifers characteristics and groundwater quality [10], little or no attention has been channeled towards assessing the vulnerability of Lafia Formation to erosion. The aim of this work is to use an integrated and easy to handle GIS tool that incorporates geoinformatics techniques for erosion and groundwater management in tropics. The proposed water management tool has two components: (a) the determination of the erosion hazardous areas, and (b) the estimation of groundwater flow and the potential contamination risk under current and future anthropogenic pressures and activities.

\section{Location and accessibility of the study area}

River Amba catchment is located in the southwest of Nasarawa State, central Nigeria. It lies between latitude $8^{\circ} 24^{\prime}$ and $8^{\circ} 36^{\prime}$ and longitude $8^{\circ} 26^{\prime}$ and $8^{\circ} 36^{\prime}$ (Fig. 1) and drains a surface area of about $800 \mathrm{~km}^{2}$ (Fig. 2) with the monitoring station is located at the outlet (coordinates: $8^{\circ} 29^{\prime} 36.4^{\prime \prime} N$ and $8^{\circ} 30^{\prime} 31.4^{\prime \prime} E$ ). River Amba is the major river that drained the area and is characterized by the Guinean savannah vegetation. The original vegetation has been tampered with due to human activities such as farming, bush burning and grazing, which has given rise to a secondary forest $[13,10]$. The area is characterized by two major distinct seasons (wet and dry), the former lasts from March to October, while the later lasts from November to February. The annual average rainfall ranges between 1000 and $1500 \mathrm{~mm}$ while the mean annual humidity is $70 \%$ with relative humidity of 60 to $80 \%$ [14].

Temperatures range from $33-36{ }^{\circ} \mathrm{C}$ with an annual average temperature of $28.5^{\circ} \mathrm{C}$. An annual average sunshine hour of 6.7 per day is also experienced. The elevations of this area range from 110 to $243 \mathrm{~m}$ above sea level. The geological bedrock is sandstone, and it is overlaid by deep and highly loose soils (Oxisols, Ultisols, and Alfisols), with the Oxisols being the dominant soil class in the catchment. These soils are enriched in iron oxides and laterite. The landscape is generally characterized by gentle slopes (3-6\%), whereas steeper slopes (5-9\%) are found near the drainage channels.

Accessibility is by the Trunk 'A' Lafia - Akwanga and further improved by minor routes and footpaths linking villages, farm lands and streams (Fig. 3). The major stream flows in northeast - southwest direction which corresponds to the strike direction of most structures generally found in the area indicating structurally controlled stream.

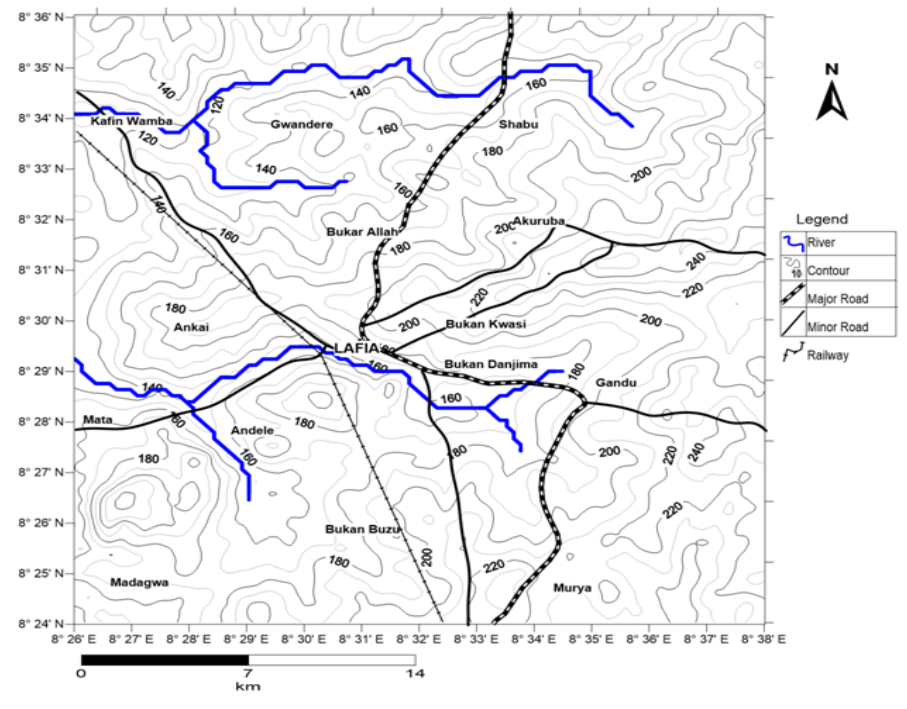

Figure 1. Topographic map of the study area.

\subsection{Geology and Land Use}

Geologically, the study area is underlain by the Laa Formation (Fig. 4) also called the 'Laa Sandstone' [15]. It lies within Central Benue Trough, Nigeria, and characterized by ferruginized sandstones, red loose sands, flaggy mudstones, clays and claystones. Hydrogeologically, the Lafia Formation comprises 


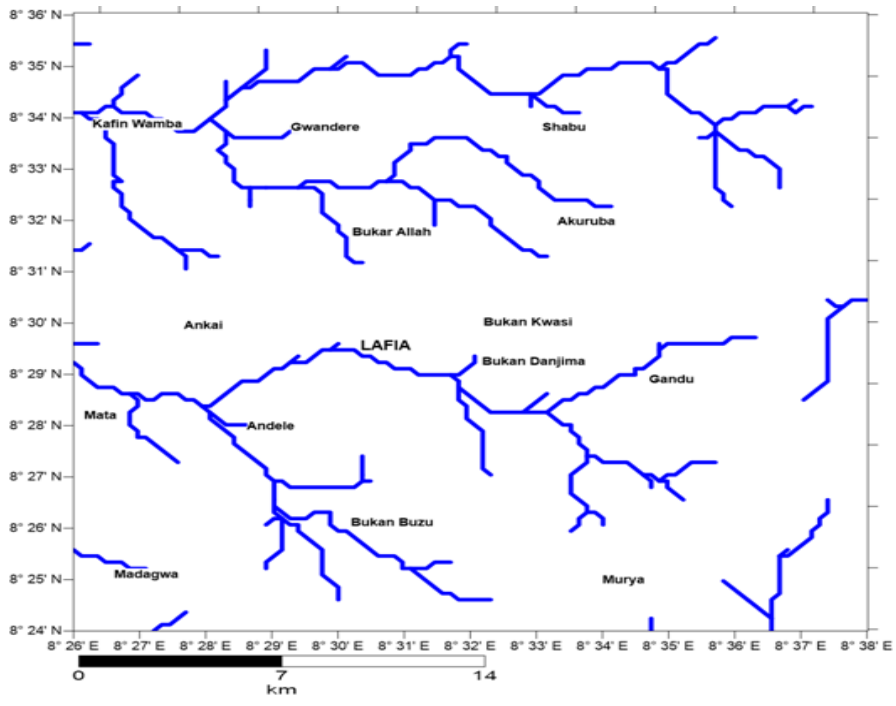

Figure 2. River Amba watershed map.

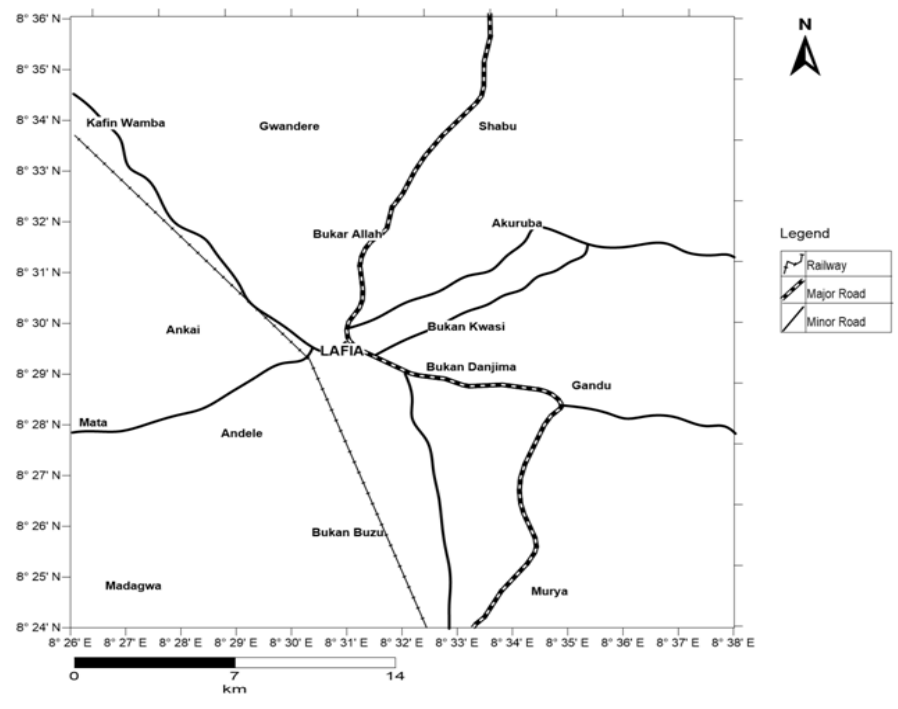

Figure 3. Accessibility map of the study area.

mainly fine-to-coarse grain sandstones, which are highly porous and permeable [13] and is the most prolific in the Central Benue Trough.

Land use including farming, forests, wetlands, and urban areas cover less than $15 \%$ of the total catchment surface area. The riparian areas $(<10 \mathrm{~m}$ wide) found along the river catchment network are narrow. They are further affected by cattle trampling, which prevents them from providing effective traps to stop sediment emanating from upper parts of the catchment.

The hydrogeology of the Lafia Formation and the Central Benue Trough has been studied by $[9,15]$ who made a brief survey of the water resources of the area in the light of its importance to the development of the region. An evaluation of some hydrogeological characteristics of the aquifers of Lafia formations [10], where he reported the aquifer to be about $150 \mathrm{~m}$ thick, highly prolific having dominantly moderate aquifer protective capacity.
Four types of aquifers were identified $[9,15]$. These are; the Awe Formation, the Keana / Ezeaku Formation, the Awgu Formation and the Lafia Formation (being the youngest). In Obi village, the Lafia sandstone is sub-artesian and quite near the surface which can be tapped for domestic and industrial purposes [16].

\section{Materials and Methods}

\subsection{Estimating the Erosion Hazardous Areas in the Amba Wa- tershed}

Based on factors that form and influence erosion; slope, land use, rainfall intensity, geology and flow accumulation the study area was divided into five regions characterized by different degrees of erosion susceptibility (very high, high, moderate, low and very low). Relative weights were assigned to each factor based on its influence in triggering erosion according to Kourgialas \& Karatzas [4]. Thematic maps are produced for each parameter in a GIS environment. A combination of these thematic maps and the selection of the weights yield the final map of erosion prone areas.

The original data include the topographic map (Fig. 1) and the monthly rainfall data (Table 1) from station located in the surrounding area. The Digital Elevation Model (DEM) for the terrain was created by Surfer 14. Remote sensing data (aerial photographs and Landsat Imagery) were used to determine the land use, while geological mapping was used to determine the geology of the watershed area. From the DEM, the flow direction in each raster cell was determined. This was followed by the identification of the water accumulation points. The flow concentration map, which indicates the number of cells that hydrologically contribute to each raster cell was developed by using the flow direction map combined with a suitable algorithm (flow accumulation - Arc Hydro). Output cells with a high flow accumulation (pixels) are areas of concentrated flow [4].

The rainfall intensity was determined from the meteorological data (2001-2011) of area surrounding the Amba watershed (Table 1). The rainfall intensity map was created by using the Modified Fourier Index (MFI) methodology [17]:

$$
M F I=\sum_{1}^{12} \frac{P^{2}}{P}
$$

where $\sum_{1}^{12}$ is the 12 -month summation, $P^{2}$ is the average monthly rainfall and $P$ is the average annual rainfall. The MFI indicator expresses the sum of the average monthly rainfall intensity at a station.

\subsection{Estimating the Groundwater Direction and Groundwater Contamination Risk in the Amba Watershed}

The static water levels (SWL) of over two hundred wells and boreholes were measured using dipper (the dipper-T model) while the topographic elevation and coordinates (latitude and longitude) of each was established using Geographical Positioning System (e-Trek 20 Garmin model). Hydraulic head for 


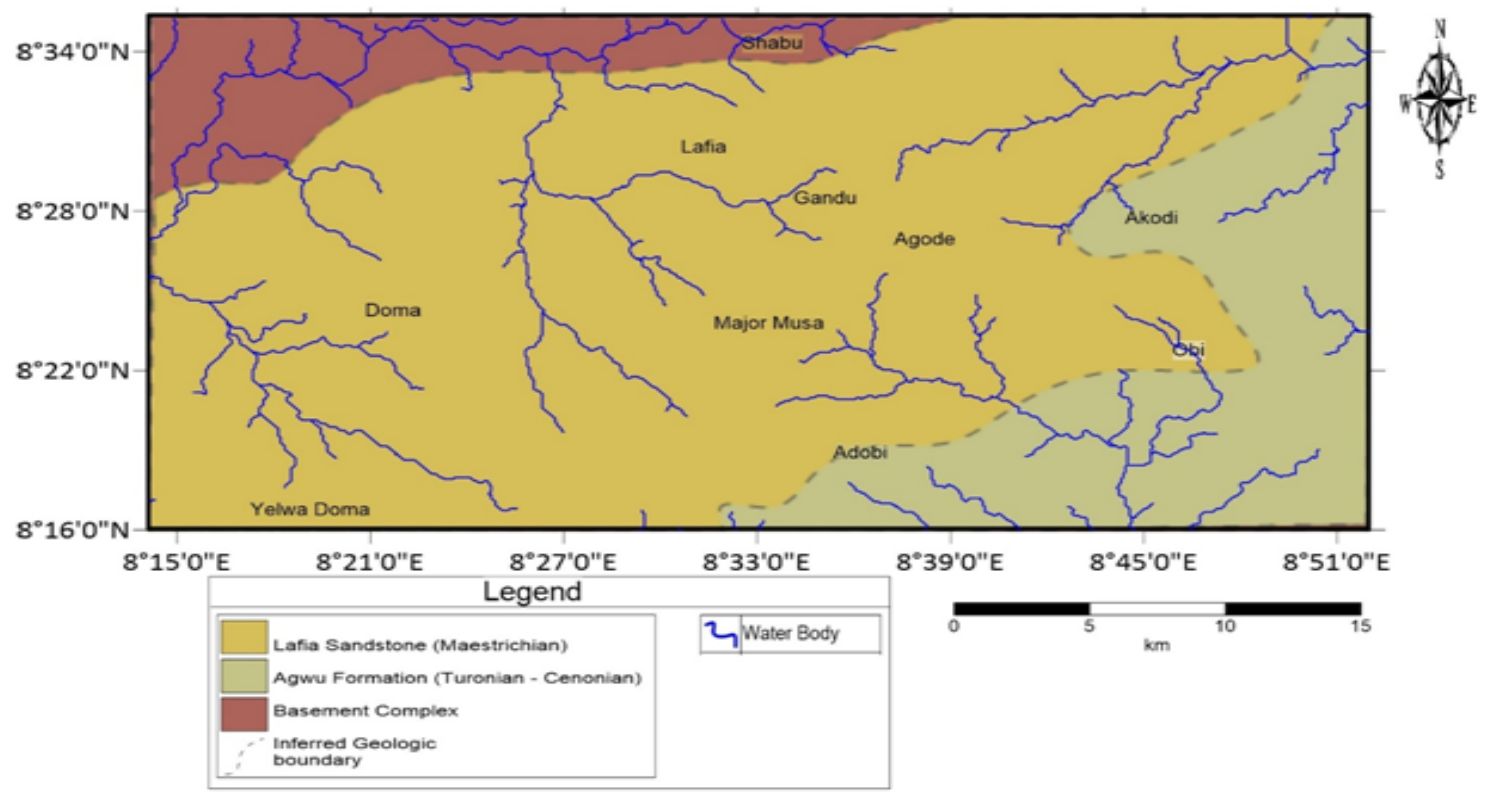

Figure 4. Geologic Map of the Amba Watershed [10].

each well was estimated from the SWL and topographic elevation above mean sea level measured for such well. These measurements were used to construct hydraulic head map. This map describes the groundwater flow direction in the study area. Groundwater contamination risk was estimated in the extended area by combining information of the equipotential contours map created in a GIS environment with lineament map of the area (Fig. 5).

The primary data for the creation of the above maps include: a) land uses based on aerial photographs, b) hydrogeological layers maps, c) soil maps, and d) groundwater level data from wells in the study area.

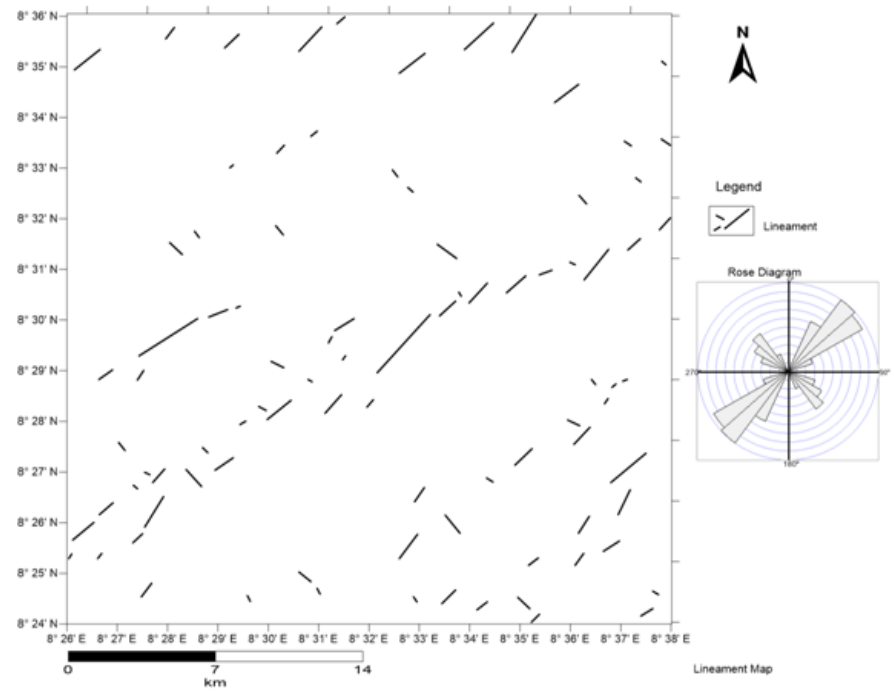

Figure 5. Lineaments Density Map of the Amba Watershed.

\section{Results and Discussion}

\subsection{Erosion Prone Areas}

The six factors viz; flow accumulation (Fig. 6), slope (Fig. 7), elevation (Fig. 8), rainfall intensity (Table 1), geology (Fig. 4), and land use (Fig. 9), were used to estimate the erosion susceptible areas and create the corresponding maps. These factors were assigned numeric values, except geology and land use which were expressed in descriptive form [4]. In the case of the numeric-valued factors, five classes of susceptibility were identified while in the case of the non-numeric-valued factors, classification depends mainly on the influence of the factor on the generation of erosion process. For instance, for the geology factor, a loamy soil indicates very low erosion vulnerability while in the case of the land use factor, limited land cover (low land cover) indicates a very high erosion susceptibility.

It is almost impossible to estimate erosion susceptibility of an area by considering the influence of a single factor, therefore the integration of all related factors is necessary in order to obtain the overall erosion vulnerability map as all factors have varying degrees of influence on the vulnerable areas. A weighting approach, where a different weight is assigned to each factor, was applied while the factor weights were determined according to Kourgialas \& Karatzas [4].

Based on this methodology, the effects of each factor on all other factors are depicted in Fig. 10. A solid line between two factors indicates that one factor has a main effect on the other pointed by the arrow, that is, a change of the first factor has a direct effect on the other (main avenue). A dashed line between two factors indicates that one factor has a secondary effect on the factor pointed by the arrow, that is, a change of the first factor has an indirect effect on the other (minor avenue). For example, flow accumulation has a main effect on land use and a secondary effect on slope. In order to quantify the two different 
Table 1. Mean Monthly Rainfall Data $(\mathrm{mm})$ from 2001 - 2011 (Source: NIMET, Lafia).

\begin{tabular}{lcccccccccccccc}
\hline YEAR & $\mathbf{2 0 0 1}$ & $\mathbf{2 0 0 2}$ & $\mathbf{2 0 0 3}$ & $\mathbf{2 0 0 4}$ & $\mathbf{2 0 0 5}$ & $\mathbf{2 0 0 6}$ & $\mathbf{2 0 0 7}$ & $\mathbf{2 0 0 8}$ & $\mathbf{2 0 0 9}$ & $\mathbf{2 0 1 0}$ & $\mathbf{2 0 1 1}$ & Mean & STD DEV \\
\hline Jan & 0 & 0 & 0 & 0 & 0 & 0 & 0 & 0 & 0 & 0 & 0 & 0.0 & 0 \\
Feb & 0 & 0 & 26 & 0 & 0 & 0 & 0 & 0 & 0 & 0 & 9.3 & 3.2 & 7.68 \\
Mar & 0.4 & 0 & 0 & 0 & 58 & 40 & 21 & 14 & 0 & 0 & 0 & 12 & 19.03 \\
Apr & 118 & 55 & 109 & 148 & 43 & 1.9 & 89 & 92 & 128 & 75 & 28 & 81 & 42.91 \\
May & 205 & 143 & 170 & 159 & 162 & 225 & 164 & 181 & 190 & 116 & 198 & 176 & 29.01 \\
Jun & 231 & 48 & 128 & 181 & 106 & 166 & 255 & 229 & 324 & 125 & 222 & 183 & 74.98 \\
Jul & 278 & 298 & 262 & 268 & 242 & 304 & 244 & 188 & 230 & 382 & 74 & 252 & 73.35 \\
Aug & 312 & 337 & 266 & 283 & 356 & 251 & 233 & 241 & 193 & 230 & 275 & 271 & 46.67 \\
Sep & 216 & 162 & 319 & 183 & 154 & 248 & 274 & 109 & 146 & 312 & 228 & 214 & 66.40 \\
Oct & 54 & 139 & 105 & 84 & 169 & 84 & 0 & 77 & 376 & 177 & 227 & 136 & 160.99 \\
Nov & 0 & 12 & 24 & 0 & 0 & 0 & 0 & 0 & 8.8 & 20 & 0 & 5.9 & 8.61 \\
Dec & 0 & 0 & 0 & 0 & 0 & 0 & 0 & 0 & 0 & 0 & 0 & 0.0 & 0 \\
Total & 1415 & 1192 & 1406 & 1305 & 1129 & 1319 & 1279 & 1136 & 1595 & 1438 & 1261 & 1316 & 529.63 \\
\hline
\end{tabular}

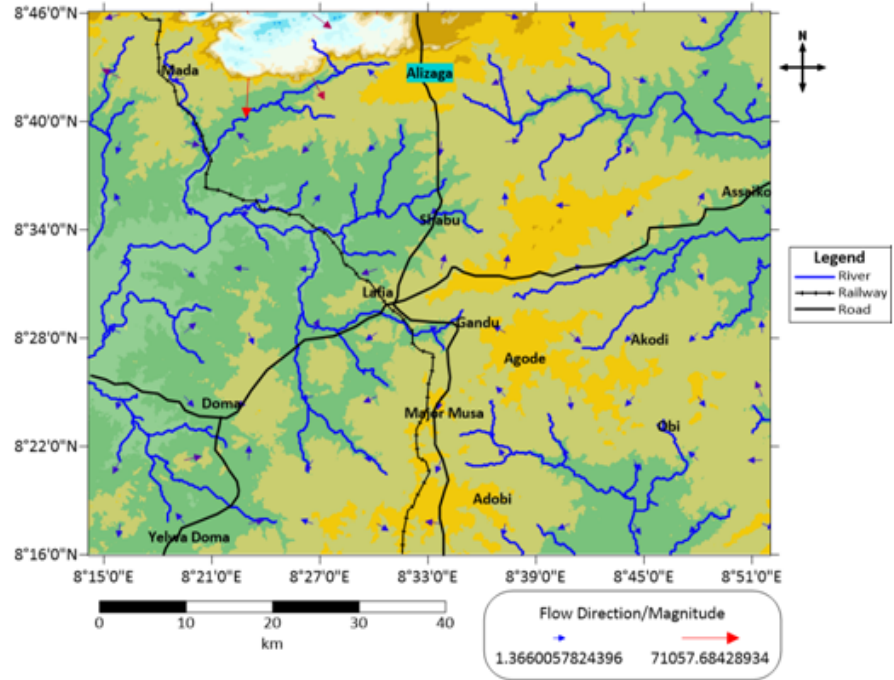

Figure 6. Flow Direction and Accumulation map of the study area (Note: colour bands show demarcation of watersheds).

types of effects, one (1) point is assigned to a main and half a point $\left(\frac{1}{2}\right)$ to a secondary effects [17]. Then, the rate for a factor is computed as the summation of the points corresponding to the effects emanating from the factor.

Based on the above weighting approach, the contribution of each factor to the erosion vulnerable areas, expressed as a percentage, is for the elevation: $31.49 \%$, land use: $21 \%$, slope: $14 \%$, geology: $12.52 \%$, rainfall intensity: $10.5 \%$, and flow accumulation: $10.5 \%$.

The resulting map of the erosion vulnerability areas includes the combination of the above six variables that are related directly to any erosion event that occurs in the watershed. Specifically, the six maps that were developed after the classification method were combined using a weighted linear combination approach in a GIS environment. Accordingly, each factor is multiplied by its percentage weight and the summation of all factors yields the final hazardous area map [18].

$$
S=\sum w_{i} x_{i}
$$

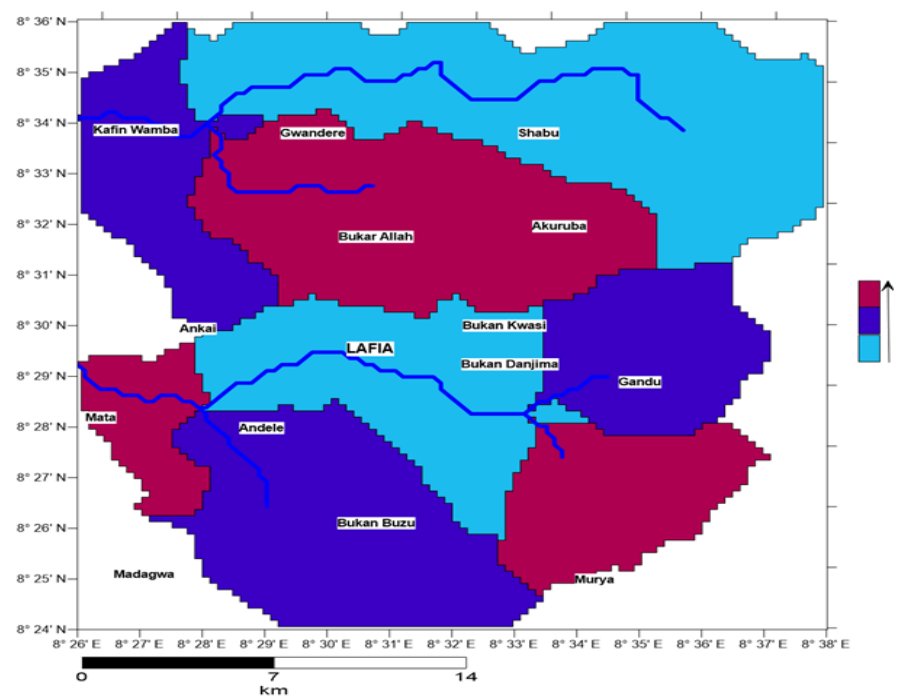

Figure 7. Slope Classification map of the study area.

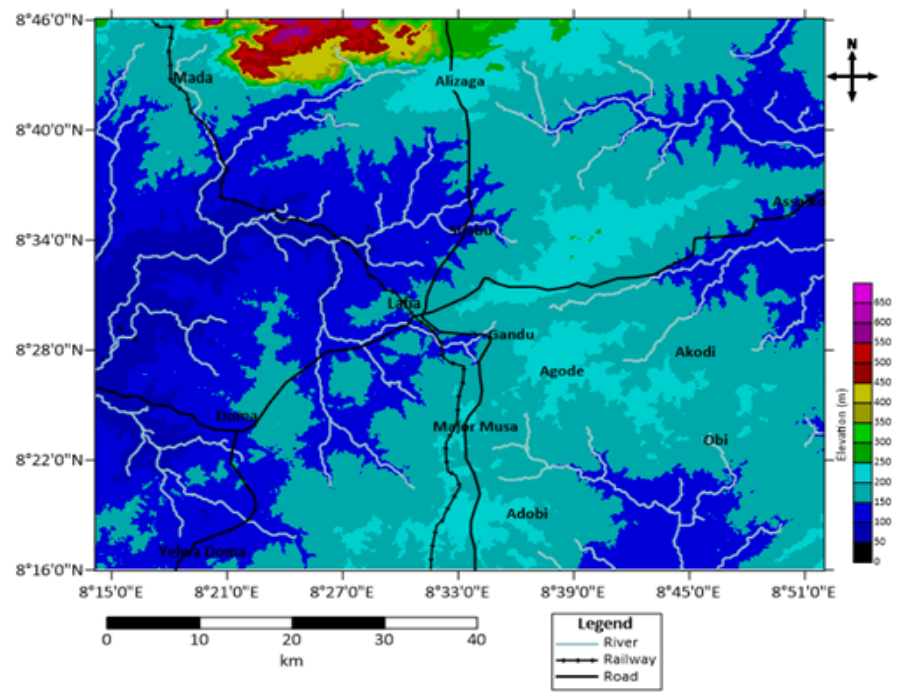

Figure 8. Elevation map of the study area. 


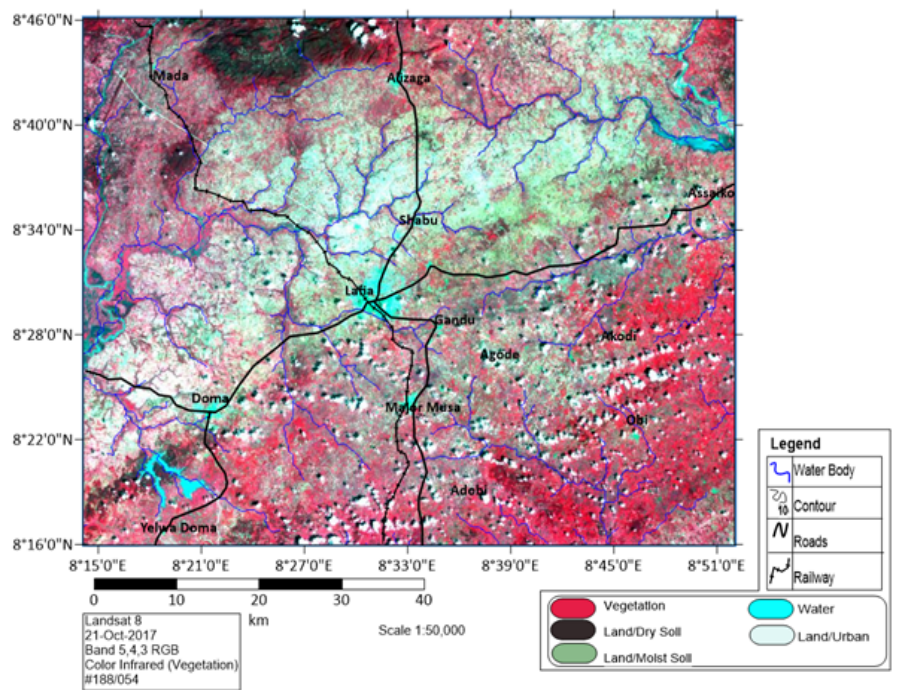

Figure 9. Land Use map of the study area.

where, $S$ is the final hazardous areas map, $w_{i}$ is the weight of factor $I$ (percentage) and $x_{i}$ is the rate of the factor $i$. The factors (maps) were combined according to Equation (2) and the final flood hazardous areas map was produced (Fig. 11). According to this figure, the study area of Amba watershed can be classified with respect to erosion hazard from high to very low. Based on the results, the south-eastern parts of the watershed can be characterized as high flood prone areas.

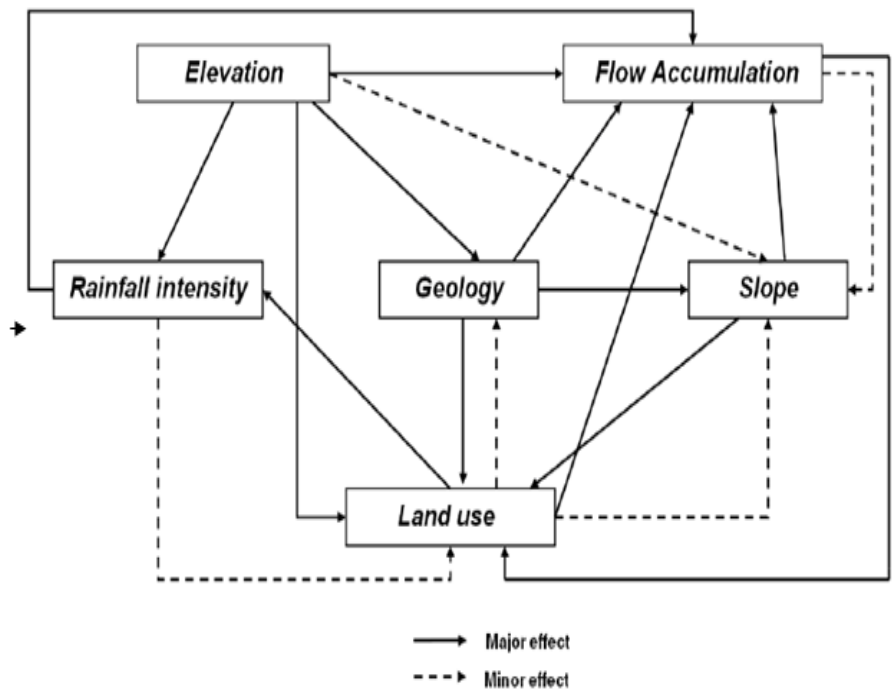

Figure 10. A Schematic Depiction of the Interaction between Factors that Influence the Flood hazard [4].

\subsection{Groundwater Risk under an Intensive Agriculture}

Due to recent agricultural activities in the study area, particularly fertilizers and pesticides application and the hypothetical scenario of charging pollutants and whether these may create environmental problems in the extended area, the map of hydraulic heads (equipotential lines) for the entire watershed area was created (Fig. 4) based on the groundwater level data from over two hundred wells. It describes the flow direction, perpendicular to the equipotential lines. The direction of groundwater flow is northwest, through this flow direction groundwater encountered various soil types of varying porosities resulting in many springs particularly at contact points.

From the study, it was observed that a) based on the groundwater level data the aquifer in the Amba watershed is shallow $(4.0-28.5 \mathrm{~m})$ [10],b)the study area receives significant amounts of rainfall, fact that lead to a rapid recharging of groundwater resources, and c) the groundwater flow in the study area discharges through the Amba river and many springs. These springs supplies drinking water to Lafia settlements and environs.

Based on the above, the highly significant groundwater contamination risk in the study area from any excessive use of agrochemicals through intensification of agricultural activity is obvious. Any deposition of contaminants such as nitrates in this area may have the final recipient of the Amba River and adjoining springs.

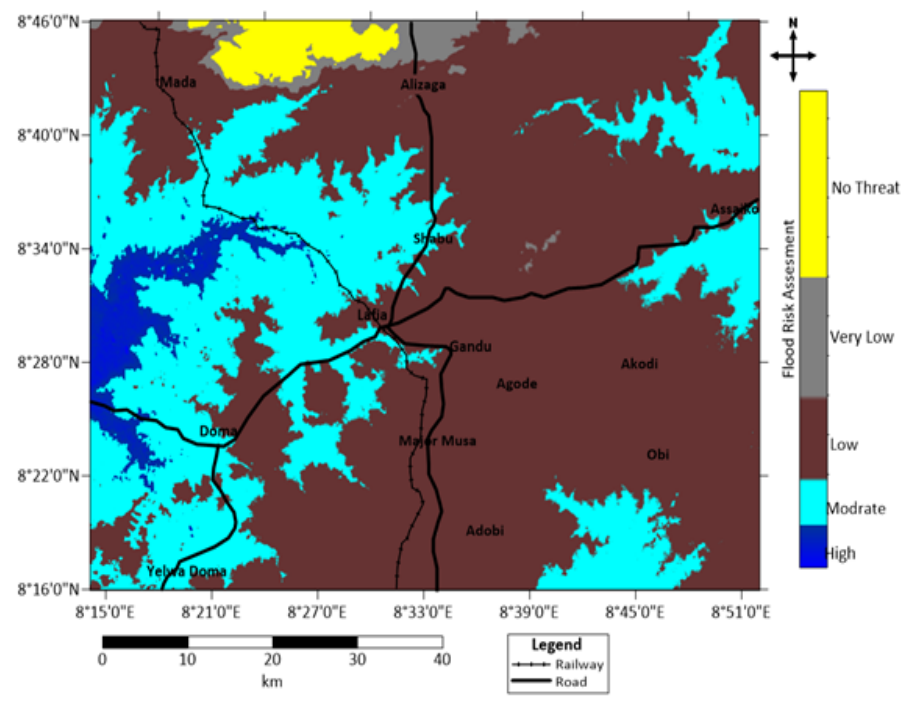

Figure 11. Erosion Vulnerability Zone Map of the Study Area.

\section{Conclusion}

This study specifically evaluated the erosion prone areas and estimated the groundwater contamination risk in the Amba watershed by utilizing a combined remote sensing and geoinformatics approach. Thus, the following conclusions based on the results of this study:

1. The erosion hazard phenomena in the study area is characterized as high in south-western part and moderate to very low in other parts of the study area.

2. The loamy soil of the Amba watershed is characterized by high clay content and shallowness. All these features contribute to a high groundwater contamination risk due to increased fertilizers and pesticides application. Regarding the possible contamination in surrounding areas, 
especially the spring, the groundwater hazard can be classified as very high.

The estimation of erosion and the groundwater hazardous areas are fundamental components of a water management strategy. This study could become a useful tool for better management plan for the Amba watershed and others which are at risk of potential erosion and the high risk of groundwater contamination.

\section{Acknowledgments}

We thank the referees for the positive enlightening comments and suggestions, which have greatly helped us in making improvements to this paper. The authors are grateful to Dr. Solomon O. Onwuka of the Department of Geology, University of Nigeria, Nsukka, for his assistance at various stages of the research.

\section{References}

[1] R. Lal, J. A. Delgado, J. Gulliford, D. Nielsen, C. W. Rice \& R. S. Van Pelt, "Adapting agriculture to drought and extreme events", Journal of Soil and Water Conservation November 67 (2012) 166. https://dx.doi.org/10.2489/jswc.67.6.162A.

[2] D. R. Montgomery, "Soil erosion and agricultural sustainability", Proc. Natl. Acad. Sci. U. S. A., 104 (2007) 13272. https://dx.doi.org/10.1073/pnas.0611508104.

[3] J. A. Ballesteros, M. Stoffel, M. Bollschweiler, J. M. Bodoque \& A. DiezHerrero, "Flash-flood impacts cause changes in wood anatomy of Alnus glutinosa", Fraxinus angustifolia and Quercus pyrenaica, Tree Physiol, 30 (2010b) 781.

[4] N. N. Kourgialas \& G. P. Karatzas, "Flood management and a GIS modelling method to assess flood-hazard areas-a case study", Hydrological Sciences Journal 56 (2011) 14.

[5] R. Lal, "Constraints to adopting no-till farming in developing countries", Soil Tillage Res 94 (2007) 1. https://dx.doi.org/10.1016/j.still.2007.02.002.
[6] S. Yahaya, N. Ahmad \& R. F. Abdalla, "Multicriteria Analysis for Flood Vulnerable Areas in Hadejia-Jama'are River Basin", Nigeria", European Journal of Scientific Research 42 (2010) 83.

[7] M. Wireman, "Characterization and Management of Ground Water Resources in Fractured-rock Hydrogeologic Settings", Groundwater Monitoring and Remediation 23 (2003) 2003.

[8] Y. M. Chiang \& F. J. Chang "Integrating hydrometeorological information for rainfall-runoff modelling by artificial neural networks", Hydrological Processes 23 (2009) 1659.

[9] S. Manfreda, A. Sole \& M. Fiorentino, "Can the basin morphology alone provide an insight into floodplain delineation", WIT Transactions on Ecology and the Environment 118 (2008) 56.

[10] M. E. Offodile, "The geology of the middle Benue trough, Nigeria", Publication from The Palaeontological Institution of the University of Uppsala, Germany, (1976a) 41.

[11] N.D. Umar, O. Igwe \& I.G. Idris, "Evaluation and characterization of groundwater of the Maastrichtian Lafia formation, Central Benue trough", Nigeria Journal of Earth System Science 128 (2019) 168. https://doi.org/10.1007/s12040-019-1199-1

[12] N.G. Obaje, U.I. Lar, A. Moumouni, M.S. Chaanda \& N.G. Goki, Geology and Mineral Resources of Nasarawa State, A Preliminary Investigation, Report of Geographical Prospective on Nasarawa State, Department of Geography Nasarawa State University, 2006.

[13] M. U. Musa Hydrogeology and groundwater quality of Lafia and its environs, sheet 231, Lafia, Nasarawa state, north central Nigeria, Unpublished Master's Thesis, Ahmadu Bello University, Zaria, 2015.

[14] P. Achohwora, Some hydrogeological aspects of the Lafia Coal Deposit, Plateau state, Unpublished Master's Thesis, Ahmadu Bello University, Zaria, 1986.

[15] N. L. Binbol, A climate of Nasarawa state; Report of Geographical Prospective on Nasarawa State, Department of Geography, Nasarawa State University, 2006.

[16] M. E. OffodilE, Groundwater study and development in Nigeria, Mecon Geology and Engineering Services Ltd. Jos, Nigeria, 2002.

[17] C. R. Cratchley \& G. P. Jones, "An Interpretation of the Geology and gravity anomalies of the Benue Valley, Nigeria", Overseas Geological Surveys Geophysical Paper 1 (1965) 26.

[18] R. P. C. Morgan, Soil erosion and conservation, Blackwell Publishing Ltd, Oxford UK, 2005. 